Portland State University

PDXScholar

1977

\title{
A Survey of Neighborhood Attitudes Toward the Mentally Retarded and Community Group Homes
}

Fred T. Cooprider

Portland State University

Follow this and additional works at: https://pdxscholar.library.pdx.edu/open_access_etds

Part of the Social Work Commons

Let us know how access to this document benefits you.

\section{Recommended Citation}

Cooprider, Fred T., "A Survey of Neighborhood Attitudes Toward the Mentally Retarded and Community Group Homes" (1977). Dissertations and Theses. Paper 1894.

https://doi.org/10.15760/etd.1893

This Thesis is brought to you for free and open access. It has been accepted for inclusion in Dissertations and Theses by an authorized administrator of PDXScholar. Please contact us if we can make this document more accessible: pdxscholar@pdx.edu. 
A SURVEY OF NEIGHBORHOOD ATTITUDES TOWARD

THE MENTALLY RETARDED AND

COMMUNITY GROUP HOMES

by

FRED T. COOPRIDER

A report submitted in partial fulfillment of the requirements for the degree of

MASTER OF

SOCIAL WORK

Portland State University

1977 
TO THE OFFICE OF GRADUATE STUDIES AND RESEARCH:

The members of the committee approve the practicum of

Fred T. Cooprider.

Dale Poteet

Nancy Kololoff

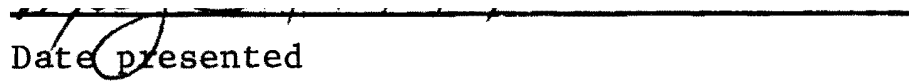


TABLE OF CONTENTS

PAGE

LIST OF TABLES

iv

CHAPTER

I INTRODUCTION 1

Definition of Terms 2

II A BRIEF HISTORY $\quad 4$

$\begin{array}{ll}\text { III REVIEW OF CURRENT RESEARCH } & 12\end{array}$

$\begin{array}{ll}\text { IV RESEARCH DESIGN } & 14\end{array}$

$\begin{array}{ll}\text { Question } & 14\end{array}$

$\begin{array}{ll}\text { Sample } & 14\end{array}$

$\begin{array}{ll}\text { Inst rument } & 15\end{array}$

$\begin{array}{ll}\text { Method of Survey } & 17\end{array}$

$\begin{array}{llr}\mathrm{V} \text { RESULTS } & 20\end{array}$

$\begin{array}{ll}\text { Demographic Data } & 21\end{array}$

General Attitudes Toware the Retarded 23

Attitudes Regarding the Entry or Presence of

Group Homes $\quad 25$

VI CONCLUDING DISCUSSION

$\begin{array}{ll}\text { Conclusions } & 31\end{array}$

$\begin{array}{ll}\text { Limitations } & 32\end{array}$

Implications $\quad 33$

Recommendation for Future Research 34

REFERENCES

$\begin{array}{ll}\text { APPENDIX } & 37\end{array}$ 


\section{LIST OF TABLES}

TABLE

PAGE

I Twenty-one Bipolar Adjective Scales of the Semantic Differential Classified by Factor and Area

II Occupational Makeup and Income of Respondents 22

III Sex of Respondents $\quad 22$

$\begin{array}{ll}\text { IV Resident Status of Respondents } & 23\end{array}$

V General Attitude Scores in Rank Order 24

VI Average Responses to Each Item Measuring General Attitude Toward the Retarded 25

VII Attitude Toward Group Homes Scores in Rank Order 26

VIII Average Responses to Statements Regarding Attitudes Toward Group Homes

IX Responses to Hypothetical Zoning Change to Permit Group Homes in Nelghborhood

$X \quad$ Relation of Fear of Loss of Property Value to Voting for Zoning Change to Permit Group Homes

XI Relation of Resident Status to Voting for Zoning Change to Permlt Group Homes 
CHAPTER I

INTRODUCTION

The report of the President's Panel on Mental Retardation in October, 1962, marked a turning point in the treatment of the mentally retarded in the United States. The policies of deinstitutionalization and normalization advocated in the 1962 Report have been adopted by professionals (group home providers, social workers, psychologists, doctors, etc.) who work with the retarded and legislators who regulate the treatment programs for the retarded. The large institutions and segregation policies of the first half of this century have become today's anathema.

There have been radical attitude changes among professionals and policy makers in the last decade and a half. But have community attitudes kept pace? Are communities ready or willing to absorb the institutionalized mentally retarded back into their neighborhoods? What impact has the deinstitutionalization already accomplished had upon community attitudes? These questions will be addressed by this exploratory research.

The subsequent chapters of this paper will cover the following subject areas: a brief history of attitudes toward and treatment of the retarded, to give an historical perspective to current developments; a review of current research of attitudes toward the retarded; a statement of the research question and the research design; the results of this research; and a concluding discussion. 
DEFINITION OF TERMS

Deinstitutionalization: Deinstitutionalization of the mentally retarded involves:(1) prevention of admission to institutions by developing community methods of care and training;(2) return to the community of institution residents who have been trained to function in various local settings; and (3) establishment of a program for maintenance and care of the mentally retarded within the community. Deinstitutionalization, as used in this paper, most often refers to part two of this definition.

Group home: A group home for the mentally retarded is usually a private home maintained and operated for the care, boarding, housing, and training of six or more mentally retarded persons. Residents in group homes are usually not related to each other or to the staff of the home. Group homes employ supervisory and training staff, and at least one staff person is on duty whenever one or more residents are in the home. Residents in group homes usually go out during the day to work or training situations in the community.

Mentally retarded: The term mentally retarded is used in this paper to designate anyone who has been institutionalized or may have in some other way ( $\underline{\mathrm{e} . \mathrm{g}}$, in the school system) received the 1 abel. Though the label has a supposed scientific basis (an I.Q. score more than one standard deviation below the mean) this researcher feels it is more often culturally defined and ascribed to those who are visibly handicapped or awkward, speech or motor impaired, or noticibly less intellectually capable. 
The term mentally retarded is used with some reluctance by this researcher as it has been officially rejected by Oregon's self advocacy group, People First, which represents people who have been given the label. However, it was felt that a substitution of one of the currently more acceptable labels (developmentally disabled, developmentally delayed, or M.R.D.D.) would be cumbersome in the text of this research and confusing to the respondents if used in the questionaire. It is also this researcher's belief that a substitution of 1 abels is a temporary solution when the real problem is the stigma attached to the label, which will be removed when a person's worth is not measured by intellectual capacity.

Normalization: The principle of normalization is described by Bengt Nirje as:

Making available to the mentally retarded patterns and conditions of everyday life which are as close as possible to the norms and patterns of the mainstream of society. (Nirje quoted in Wolfensberger, (1972), p.27) 
CHAPTER II

\section{A BRIEF HISTORY}

As this research is concerned with attitudes, the history presented here shall deal with the evolution of American attitudes toward the mentally retarded. To understand the history of the treatment of the mentally retarded in the United States one must understand these attitudes. Wolfensberger (1969) states:

... attitudes toward deviance generally have had much to do with the original rise of institutions for the retarded in the United States, and with the way the more common residential models were shaped. (p.89)

In this country's early history mental retardation was not differentiated from other forms of deviance. The first house of corrections in Connecticut in 1722 was for "...rogues, vagabonds, the idle, beggars, fortune tellers, diviners, musicians, runaways, drunkards, prostitutes, pilferers, brawlers, and the mentally afflicted." (Wolfensberger, 1969, p.65) A common practice in America as late as about 1820 was the public "selling" of various dependent classes (aged paupers, the sick, the mentally retarded) to the lowest "bidder" (‥e., the person who would take responsibility for them at the lowest public cost). The mentally retarded were not viewed as a special class deserving differential treatment until the mid 19 th Century.

Simultaneously in Europe and America several reformers became concerned with the condition and treatment of the mentally retarded. Johann Jacob Guggenbuhl in Switzerland, Edouard Seguin in France and later in America, and Samuel Gridley Howe in America were pioneers 
in the development of separate institutions for the education and care of the retarded. The first such institution in America was founded in 1848, in Boston, under Howe's directorship and largely through his efforts. The goal of these early institutions was "...a combination of diminishing the intellectual impairment and increasing adaptive and compensatory skills of the pupil so that he would be able to function at least minimally in society." (Wolfensberger, 1969, p.89) These early institutions were built on a developmental model. The emphasis was on the development, through special training, of sufficient skills to survive in and contribute to society. The largest facilities were built to house about fifty residents and they were not intended by their founders to evolve, as they did, into custodial institutions.

A combination of factors forced a change in these early institutions. Those residents less amenable to training and those who could have been partially habilitated, but had no supervised facility to return to in the community, began to swell institution populations. With the failure of these institutions to live up to their original high expectations, Ideologies began to change between 1870 and 1880 . Wolfensberger (1969) states:

Developmental attitudes degenerated into pity and charity, and as they did, the residential model changed from a developmental one to a pity model. The idea grew that retardates should be viewed as innocent victims of fate or parental sin, and that instead of schooling, loving care and protection should be bestowed upon them. (p.95)

Institutions grew in size and, for the residents' "protection," were isolated from the community. Institutions were constructed in the country and even Howe's school was relocated in 1887 from its urban setting in South Boston to a more secluded spot in Waltham. The term 
"school" began to be replaced by "asylum." In 1893 the Custodial Asylum for Unteachable Idiots was founded at Rome, New York. Little was expected from the residents of these institutions except the performance of some maintenance and agrarian tasks to defray the pub1ic cost. Viewing the retarded as objects of pity gradually gave way to a perception of the retarded as a menace to society. In 1912 Goddard wrote The Kallikak Family, in which he traced the descendants of a sexual encounter between a revolutionary soldier of normal intelligence (pseudonym Martin Kal11kak) and a "feebleminded girl" he met in a tavern. This family history supposedly demonstrated the hereditary nature of mental retardation and documented the high incidence of crime, prostitution, alcoholism, and general anti-social behavior among the Kallikaks. Although Goddard's research methods were less than scientific his conclusions were widely accepted. Goddard spoke for many of his contemporaries when he stated:

For many generations we have recognized and pitied the idiot. of late we have recognized a higher type of defective, the moron, and have discovered that he is a burden; that he is a menace to society and civilization; and that he is responsible to a large degree for many, if not all, of our social problems. (Goddard quoted in Wolfensberger, 1969, p. 102-3)

The indictment of the mentally retarded had begun before Goddard's book and it reached its peak in the first two decades of the 20th Century. During this period of indictment there were three measures for preventing the increase of mental retardation: (1) preventive marriage laws; (2) eugenic sterilization laws; and (3) segregation. Marriage and sterilization laws were recognized early as ineffective and difficult to administer. Such laws gradually fell into disrepute and though some are still existent they are seldom 
enforced.*

With the recognition of the ineffectiveness of marriage and sterilization laws, segregation became the main weapon in combatting the "menace" of retardation. Professionals in the field advocated institutionalization not only to protect society but for reasons of economy as we11.

As a simple business proposition no state can make a better investment, or one actually paying larger dividends, than to insure that the feeble-minded women of child-bearing age are prevented from bringing defective paupers into the world to go on reproducing themselves in geometrical ratio. The direct money saving from this result alone in a few generations would represent a sum equal to the cost of maintenance of the entire feeble-minded population of the state. (Fernald quoted in Wolfensberger, 1969, p. 117)

Segregation was widely accepted as evidenced by the expansion of institutions in the United States during the first half of this century. In 1904 there were 17.5 institutional places (commonly refered to as "beds") per 100,000 population; 22.5 by 1910 ; 39.3 by 1923 ; 66.1 by 1956; and 98.1 by 1966 . (Wolfensberger, 1969, p. 125)

Attitudes regarding the retarded as a "menace" began to change in the $1920^{\prime}$ s and $30^{\prime} \mathrm{s}$. Further scientific research dispelled the notion that all mental deficiency was hereditary in nature and follow-up studies of released institution residents showed that the retarded were not inclined to lives of crime or anti-social behavior. Despite this new evidence institutions continued to grow and segregation remained society's primary response to mental retardation. The institution

*Oregon's eugenic sterilization law, though amended from its original version in 1917, is still on the books. The last eugenic sterilization performed in Oregon was in 1975. The Board of Social Protection, which administers the law, has not been funded by the legislature since 1975 and thus the law is not now applied. 
movement retained its momentum despite its loss of a rationale. Society had made up its mind and did not want to be confused by the facts.

But the facts would not go away. Large institutions began to be recognized as dehumanizing warehouses. Beginning in the 1950 's several factors lead to a change in the treatment of the mentally retarded away from institutionalization and toward community based services. The National Association for Retarded Chlldren (N.A.R.C.) was organized in 1950 and had a membership of 50,000 by 1959. (Kanner, 1964, p. 143) N.A.R.C. members, consisting of concerned parents and friends of the retarded as well as professionals in the field, advocated for more scientific research, improved public attitude, and better treatment for the retarded. (The organization remains today the N.A.R.C., though the initials now stand for the National Association for Retarded Citizens.) Another milestone of the 1950's was New York's Innovative Community Mental Health Services Act of 1954, which called for the "development of preventive, rehabilitative and treatment services through new community mental health programs and improvement and expansion of existing community services." (Kressel, 1975, p. 140) A major turning point in treatment policy came on October 17, 1961, with the appointment by President John F. Kennedy of the President's Panel on Mental Retardation. One year from that appointment the Panel submitted its report to the President, A Proposed Program for National Action to Combat Mental Retardation. This report was greatly influenced by European treatment models that were observed by some Panel members. In the section of the report titled "The Role of Residential Care," the following objectives were stated:

No child or adult should remain in residential care any longer than necessary. Regular and frequent reevaluations must be scheduled 
to reveal possibilities that may have been developed in his community and to determine whether the individual himself has reached the point where he may profit by some other form of care.

If and when the child or adult is ready for return to the community, adequate resources and services for his support should be made available. It may not be wise or possible for some to return to their own families, hence the importance of developing foster or boarding placement, or homes for small groups similar to those in several European countries. (President's Pane1, 1962, pp. 137-138)

Several states, with the aid of federal funds, used this 1962

Panel Report as a model for state plans and policies. Oregon developed such a plan in 1965 (Oregon, 1965) which called for an end to segregation policies in the treatment of the mentally retarded. Oregon's state institution for the retarded, Fairview Hospital and Training Center (F.H.T.C.), is located in Salem, and thus much of the early deinstitutionalization took place in Salem. One neighborhood in Salem has three group homes and for that reason was selected to be surveyed for this research.

It is an older neighborhood with a mixture of large and small homes, some commercial zoning, and located relatively close to the downtown district. The three group homes are Spruce Villa, The Grotto, and King of Hearts. Spruce Villa was the first home established in the neighborhood in 1971 and the owners were granted a zoning variance for the particular location of their group home. The Grotto was established in 1973 by a woman who had previously provided foster care for mentally retarded adults. She was forced by zoning regulations to move from another neighborhood in Salem when she had more than the five residents allowed in foster care. She sought to establish a group home in various neighborhoods but was thwarted by zoning regulations and resistant neighbors, and finally, in 1973, acquired the present location of The Grotto which is zoned multiple dwelling residential, in which 
group homes are allowed. The King of Hearts was at first a room and board facility that took in some former residents of F.H.T.C. Its present owner acquired it in 1973 and has converted it to a group home that provides entirely for mentally retarded clients. Spruce Villa and The Grotto provide for female clients and King of Hearts provides for male clients.

Some group homes in Oregon have been started or assisted by state funds, but that was not the case with these homes. The starting capital for each of these group homes was provided by their respective owners.

These group homes provided the community residential setting for some of the first clients deinstitutionalized out of F.H.T.C. A social worker from F.H.T.C. was released from other duties to assist these deinstitutionalized clients in their adjustment to group home and community life. Some of the most capable residents of F.H.T.C. were the first to be deinstitutionalized and many of them have moved on to independent living situations. As less capable clients began to be deinstitutionalized, these group homes developed more stable populations of clients who have need of the supervision provided in a group home.

If deinstitutionalization is to continue, more group homes will need to be established to provide for the less capable F.H.T.C. residents. The success of further deinstitutionalization may depend upon community attitudes and willingness to accomodate more group homes, thus the importance of determining what those attitudes are.

The current policies of deinstitutionalization and normalization may or may not reflect the attitudes of the comunity. Kressel (1975) points out that these policies and community attitudes may be in direct opposition. 
... it can scarcely be doubted that legislatures ... unwittingly set collisions in motion. This of ten occurs when reform is pursued on a national or state-wide basts without special reference to conflicting local interests. The fallure to anticipate local opposition may frustrate or undo otherwise carefully concelved social reforms. One example is the recent use of zoning barriers as a means of thwarting federal and state "normalization" programs - programs designed to return institutionalized persons to communitles in various group living arrangements. (pp. 137-138)

That communities have opposed the entry of group homes is a matter of court record. The nature and extent of the community attitudes that have caused that opposition are not as well documented. 
CHAPTER III

REVIEW OF CURRENT RESEARCH

There has been very little research of attitudes toward the retarded. Taylor (1975) states that, despite the recommendation of the President's Panel on Mental Retardation for studies "that will assess the range and variabillty of attitudes, beliefs and information in various segments of the community," the research is "fragmentary, incomplete, and suggestive at best." (p. 100) Lippman (1972) states:

Although there was a fair amount in print about services for the mentally retarded in Europe, there was suprisingly little about attitudes, either in this country (U.S.) or abroad. (p. x)

One of the latest volumes of the International Review of Research In Menta1 Retardation (E11is, 1974) states that "the relationship between community attitudes toward retardates and postinstitutional adjustment has been virtually ignored." (p. 166)

A11 of the research on attitudes toward the retarded found by this researcher were directed toward specific populations and/or situations. For example, Daily (1974) and his associates studied the attitudes of attendants in institutions and determined that attendants were biased and showed preferential treatment to certain residents. Goroff (1967) and a group of M.S.W. graduate students studied the reasons for community placed residents being returned to an institution. They discovered evidence of a double standard as many of these returns were for what Goroff called "inconsequential" behavior (behavior that would receive no sanction if exhibited by a "normal" person). Peterson (1974) 
found a direct correlation between positive attitudes of nonretarded children toward their educable mentally retarded peers and the amount of exposure or interaction between these two groups. Greenbaum and Wang (1967) developed an instrument to measure general attitudes toward the retarded (which w111 be discussed at length later as that instrument has been adapted for this research) but they restricted their study to four specific groups: (1) parents of mentally retarded children; (2) professional experts; (3) paraprofessional workers; and (4) business executives.

With the exception of Greenbaum and Wang, this researcher found no research that measured general attitude toward the retarded, nor was research found that examined attitudes toward deinstitutionalization, or more specifically toward the placement of group homes for the retarded in the community. Because so little research was found to either use as a mode1 or lend support to a hypothesis, the research presented here will be exploratory in nature. 
CHAPTER IV

RESEARCH DESIGN

QUEST ION

The questions that will be addressed by this research are: (1) what is the nature of community attitudes toward the retarded and specifically toward the entry of group homes for the retarded into the community; and (2) has the entry of existing group homes into the community had an effect on those attitudes?

This research is exploratory in nature. It will measure the attitudes of one specific type of nelghborhood and its results are not meant to be generalized to other types of neighborhoods. No hypothesis is proposed regarding whether the presence of group homes has a positive or negative effect upon community attitudes.

\section{SAMPLE}

Two neighborhoods in the city of Salem, Oregon were selected and a $10 \%$ random sample of households was selected from each neighborhood. Nelghborhood A was selected because of the presence of three group homes within its perimeter. These group homes are located so that at least one of them is within five blocks of any residence in the neighborhood, and they have all been in the neighborhood for at least three years (they were established in $4-71,5-73$, and 11-73). Neighborhood B was selected because of its similarity to Nelghborhood A vis a vis the variables of zoning (both neighborhoods have a mixture of 
commercial, multiple dwelling residential, and single dwelling residential zoning), age and appearance of homes, and proximity to the business or downtown district.

\section{INSTRUMENT}

A questionnaire (see Appendix) was designed to determine:

(1) attitudes toward the retarded in general; (2) attitudes toward the presence or possible entry of group homes for the retarded in the respondents' neighborhood; and (3) certain demographic data about the respondents.

The first part of the questionnaire is a bipolar adjective scale. modeled after an instrument designed by Greenbaum and Wang (1965). The original instrument consisted of twenty-one bipolar adjectives, 1 isted in Table I, taken from Greenbaum and Wang (1965, p. 260).

\section{TABLE I}

TWENTY-ONE BIPOLAR ADJECTIVE SCALES OF THE SEMANTIC DIFFERENTIAL CLASS IF IED BY FACTOR AND AREA

\begin{tabular}{|c|c|}
\hline Factor Classification & Area Classification \\
\hline $\begin{array}{l}\text { *1. Vvaluation Factor } \\
\text { *2. Cleable - Worthless } \\
\text { 3. Tasty - Dirty } \\
\text { Activity Factor } \\
\text { 1. Fast - Slow } \\
\text { 2. Active - Passive } \\
\text { 3. Hot - Cold } \\
\text { 1. Potency Factor } \\
\text { 2. Strong - Wmall } \\
\text { 3. Deep - Shallow }\end{array}$ & $\begin{array}{l}\text { *1. Soctal-Stimulus Area } \\
\text { to get along with } \\
\text { *2. Neat - Sloppy } \\
\text { *3. Not dangerous - Dangerous } \\
\text { 4. Self reliant - Dependent } \\
\text { *5. Rellable - Unreliable } \\
\text { *1. Health Area } \\
\text { 2. Noalth - Sick } \\
\text { Physically handicapped } \\
\text { 1. Psychological-Attributes Area } \\
\text { 2. Intelligent - Unintelligent } \\
\text { *3. Calm - Emotional } \\
\text { 4. Independent - Suggestible } \\
\text { 5. Relaxed - Tense }\end{array}$ \\
\hline
\end{tabular}

*Bipolar adjectives used in this research. 
This 1ist of twenty-one bipolar adjectives was reduced to eight because this researcher felt the entire 1 ist would tax the patience of most respondents. The eight sets of adjectives were subjectively chosen as the attitudinal factors which would reflect the respondents willingness to accept the mentally retarded in the community. The respondents were asked to identify their attitude by indicating their position on a scale of one to seven between each of the sets of bipolar adjectives.

The second part of the questionnaire was devised by this researcher after interviews with the owners of the three group homes in Neighborhood A and with Dennis Heath, a F.H.T.C. staff member who has been involved with deinstitutionalization in Salem. During the course of these interviews community opposition to group homes was discussed and the objections or concerns raised most often by community residents are reflected in the first five questions of part two of the questionnaire. The respondents were asked to respond to these attitudinal statements on a five point scale from "strongly agree" to "strongly disagree." Question six of part two simply asks if the respondent is in favor of or opposed to group homes, but it asks the question indirectly by asking the respondent if he/she would vote yes or no to a zoning change to allow a group home into his/her neighborhood. Question seven is to determine if the residents of Neighborhood A are aware of the presence of group homes in their neighborhood. Part of this research is to determine if the presence of group homes in neighborhoods affects attitudes and it is assumed that if that presence goes unnoticed it will have no effect. 
The demographic data collected in part three of the questionnaire was to account for certain variables between the two samples. Greenbaum and Wang found some evidence that variables of socioeconomic class, sex, and age affected attitudes toward the mentally retarded. This researcher assumed that the variables of time of residence, ownership of home, and number of people in the household might also affect the results of this research. As these variables could not be controlled before the samples were selected, this data was collected during the research. The possible effects of these variables on the results of this research will be analyzed in the results section of this paper.

\section{METHOD OF SURVEY}

A pilot survey was conducted on ten residences in a neighborhood in the city of McMinnville, Oregon. McMinnville was chosen for convenience as it is the city of residence of this researcher. The neighborhood was chosen for its similarity to the neighborhoods to be surveyed in Salem (i.e., older homes close to the downtown district).

It was determined during the pilot that the survey took approximately ten minutes to complete. Thus when the survey was conducted in Salem the respondents were informed that the survey would take about ten minutes of their time.

It was found during the pilot survey that some clarifying instructions were necessary. If a respondent had difficulty understanding how to respond on the seven point scales in the first part of the questionnaire, it was explained that a response of four would be neutral between the set of opposite adjectives and any other response would be weighted in one direction or the other. 
In part two of the questionnaire in the pilot survey respondents were asked to agree or disagree with the statement, "I believe mentally retarded people have a right to live in the community." Some respondents appeared to be uncomfortable with the obvious contradiction of agreeing with this statement and also agreeing with some of the other statements that would indicate a reluctance to have mentally retarded people reside in their neighborhood. The above statement was dropped from the final questionnaire as it was felt that it might inhibit some respondents from registering their true feelings.

All of the interviews were conducted by this researcher. A pattern of introductory and explanatory statements was developed during the pilot survey to keep the interviews as consistent as possible. The responddents were asked to read the directions and respond to part one of the questionnaire on their own. Before part two was administered this researcher read a definition of group homes (see Appendix) and then gave the respondent a card with the five possible responses. The researcher then read the statements and recorded the responses. The demographic data questions of part three were also read by this researcher and the responses recorded.

The survey was conducted in Neighborhood B on one weekend and in Neighborhood A on the subsequent weekend. It was randomly determined to survey Neighborhood B first. The surveys were conducted in each neighborhood from $8 \mathrm{a} . \mathrm{m}$. to $4 \mathrm{p} . \mathrm{m}$. on Saturday and from $1 \mathrm{p} . \mathrm{m}$. to $4 \mathrm{p} . \mathrm{m}$. on Sunday: A random starting point was selected in each neighborhood and then every eighth residence was surveyed. If a residence was found unoccupied the adjacent residence was tried until a respondent was found at which time an interval of eight was resumed. Respondents who refused 
to be interviewed were counted as refusals and the adjacent residence would not be surveyed and the interval of eight would be maintained. Each residential unit in apartment complexes and duplexes was counted in the intervals of eight, but businesses and vacant lots were not. 
CHAPTER V

\section{RESULTS}

The following results section will analyze and compare the data collected in both neighborhoods regarding: (1) demographic variables; (2) attitudes toward the mentally retarded in general; and (3) attitudes toward the presence or entry of group homes into the neighborhoods surveyed.

Before the results are presented, it needs to be explained that an unexpected complication was encountered during the survey. In response to question seven, part two of the questionnaire ("Are there now any group homes for mentally retarded people within ten blocks of your home?") four respondents in Neighborhood B replied "yes." It was subsequently learned by this researcher that there is a group home for mentally and emotionally disturbed (M.E.D.) clients near Neighborhood B, located one block outside of its perimeter.

Nelghborhood B was selected for its lack of group homes for mental1y retarded clients as this research was designed to compare the attitudes of two similar neighborhoods, one in which there are group homes for the mentally retarded, one in which there are not. The existance of a group home for M.E.D. clients near Neighborhood B was an unplanned variable that could affect the attitudes of Neighborhood B residents. However, it can be assumed that the existance of such a group home would have an effect on the attitudes of only those residents who know if its existance. Thus, the responses of the four Neighborhood B 
residents who were aware of the group home were discarded. Of the remaining twenty-six respondents, nine stated they did not live within ten blocks of a group home, seventeen stated they did not know.

In Neighborhood A twenty-eight respondents were aware that they lived within ten blocks of a group home for the mentally retarded, two respondents stated they did not know. Neighborhood A was selected to determine if the presence of group homes has affected neighborhood residents' attitudes. The two respondents who replied they did not know if they lived near a group home could not have had their attltudes affected by something of which they are not aware, and their responses were also discarded.

Thus the following results section will compare the responses of twenty-six respondents in Nefghborhood $B$ who either stated that there was no group home for the mentally retarded in their neighborhood or they were unaware of one, with the responses of twenty-eight respondents in Nelghborhood A who were aware that there was at least one such group home in their neighborhood.

DEMOGRAPHIC DATA

The data collected indicates that these two neighborhoods are remarkably similar. Table II (p. 22) shows the occupational makeup and annual incomes of the two neighborhoods.

Nelghborhood A has a slightly higher number of retired persons, which may account for the slightly higher average age of Neighborhood A (44.2 years) as compared to Neighborhood B (37.8 years). In general the two nelghborhoods appear to be very middle class in terms of occupation and income. 
TABLE II

OCCUPATIONAL MAKEUP AND INCOME OF RESPONDENTS

\begin{tabular}{|c|c|c|c|c|}
\hline & \multicolumn{2}{|c|}{ Neighborhood A } & \multicolumn{2}{|c|}{ Neighborhood B } \\
\hline $\begin{array}{l}\text { Occupation of respondents: } \\
\text { housewife } \\
\text { professional } \\
\text { skilled } \\
\text { unskilled } \\
\text { retired } \\
\text { unemployed } \\
\quad \quad \text { totals }\end{array}$ & $\begin{array}{r}n \\
4 \\
11 \\
5 \\
1 \\
6 \\
\frac{1}{28}\end{array}$ & $\begin{array}{r}\% \\
14.3 \\
39.3 \\
17.8 \\
3.6 \\
21.4 \\
3.6 \\
100.0 \%\end{array}$ & $\begin{array}{r}\mathrm{n} \\
5 \\
10 \\
7 \\
0 \\
2 \\
2 \\
26\end{array}$ & $\begin{array}{c}\% \\
19.2 \\
38.5 \\
26.9 \\
0 \\
7.7 \\
7.7 \\
100.0 \%\end{array}$ \\
\hline $\begin{array}{r}\text { Income of respondents; } \\
0 \text { to } \$ 10,000 \\
\$ 10,000 \text { to } \$ 20,000 \\
\$ 20,000 \text { and above } \\
\text { totals }\end{array}$ & $\begin{array}{r}n \\
9 \\
14 \\
5 \\
28\end{array}$ & $\begin{array}{l}\% \% \\
32.1 \\
50 \\
\frac{17.8}{99.9 \%}\end{array}$ & $\begin{array}{r}n \\
8 \\
11 \\
5 \\
24\end{array}$ & $\begin{array}{l}\% \\
33.3 \\
45.8 \\
20.8 \\
99.9 \%\end{array}$ \\
\hline
\end{tabular}

*Totals less than $100 \%$ due to averaging, totals less than 28 for Neighborhood A or 26 for Nelghborhood B due to invalid responses or refusals by some respondents to answer all questions.

Table III illustrates the number of male and female respondents in each neighborhood, showing more female respondents in both neighborhoods with a slightly larger majority of females in Neighborhood A.

TABLE III

SEX OF RESPONDENTS

Neighborhood A Neighborhood B

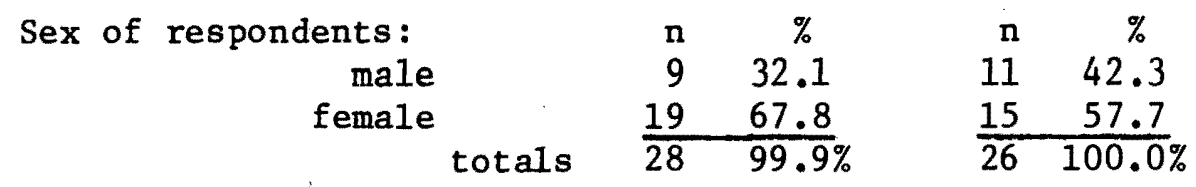


Table IV shows the resident status of respondents in both neighborhoods.

TABLE IV

RESIDENT STATUS OF RESPONDENTS

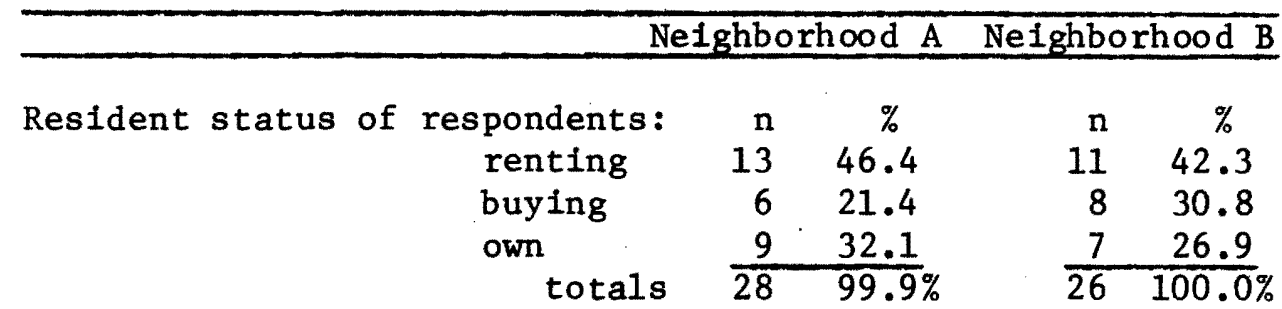

The resident status of both neighborhoods was very similar, as were the average number of residents per household (2.68 in Neighborhood A; 3.04 in Neighborhood B) and the average number of years the respondents have resided in the neighborhood ( 7.07 years in Neighborhood A; 6.88 years in Nelghborhood B).

In general these neighborhoods appear quite similar in all the demographic variables measured during the survey. If there is a significant difference in their attitudes toward the mentally retarded, it would not be due to any of the above mentioned demographic variables, and could be due to the presence of group homes in Neighborhood A.

\section{GENERAL ATTITUDES TOWARD THE RETARDED}

An average score for part one of the questionnaire (which measured general attitude toward the retarded) was computed for each respondent by adding the numerical response to each set of opposite adjectives and dividing by eight. Because of the way the responses are arranged on the questionnaire, a low numerical average indicates a positive attitude 
toward the retarded and a high numerical average indicates a negative attitude.

Table $\mathrm{V}$ shows the average scores in rank order and the group average scores for Neighborhoods A and B.

TABLE V

GENERAL ATTITUDE SCORES IN RANK ORDER

\begin{tabular}{cc}
\hline $\begin{array}{c}\text { Neighborhood A } \\
\mathrm{n}=23\end{array}$ & $\begin{array}{c}\text { Neighborhood } \mathrm{B} \\
\mathrm{n}=26\end{array}$ \\
\hline 1.62 & 1.38 \\
1.75 & 1.75 \\
2.00 & 1.75 \\
2.00 & 1.88 \\
2.25 & 2.25 \\
2.50 & 2.50 \\
2.62 & 2.62 \\
2.88 & 2.62 \\
3.00 & 2.62 \\
3.00 & 2.75 \\
3.12 & 2.88 \\
3.25 & 2.88 \\
3.50 & 2.88 \\
3.50 & 3.12 \\
3.62 & 3.25 \\
3.62 & 3.38 \\
3.75 & 3.38 \\
3.88 & 3.50 \\
4.00 & 3.62 \\
4.00 & 3.62 \\
4.00 & 3.75 \\
4.12 & 3.75 \\
4.38 & 3.75 \\
& 3.75 \\
& 4.00 \\
& 4.25 \\
\hline 3.15 & 3.00 \\
&
\end{tabular}

The responses of the two neighborhoods are strikingly similar. A $t$ test of statistical significance was not done as the difference in the group average scores is so slight as to be obviously insignificant. 
Table VI shows the average response of both neighborhoods to each of the eight sets of opposite adjectives. Not only are the average responses of both nelghborhoods very similar, but also their responses to each set. It is interesting to note that the lowest numerical response in both neighborhoods is for set five (not dangerous/dangerous), suggesting that in both neighborhoods the least likely negative attitude toward the mentally retarded is that they are dangerous.

TABLE VI

AVERAGE RESPONSES TO EACH ITEM MEASURING

GENERAL ATT ITUDE TOWARD THE RETARDED

opposite adjective sets Neighborhood A Neighborhood B

1. valuable / useless

2. dirty / clean

3. easy to get/hard to get along with/ along with

4. neat / sloppy

5. not dangerous / dangerous

6. reliable / unrellable

7. healthy / sick

8. calm / emotional

\begin{tabular}{ll}
2.88 & 2.77 \\
2.96 & 2.77 \\
2.96 & 2.85 \\
3.23 & 3.35 \\
2.85 & 2.15 \\
3.50 & 3.00 \\
3.22 & 3.23 \\
3.62 & 3.85 \\
\hline 3.15 & 3.00
\end{tabular}

2.88

.77

.85

3.35

2.15

3.00

3.00

\section{ATTITUDES REGARDING THE ENTRY OR PRESENCE OF} GROUP HOMES

An average score for part two of the questionnaire (which measured attitudes toward group homes) was computed by adding the numerical responses to the first five statements in part two and dividing by five. An average response of less than three indicates a general aversion to group homes in the respondent's neighborhood, an average response of more than three indicates a general tolerance of group homes.

Table VII shows the average scores in rank order and the group 
average score for Neighborhoods $A$ and $B$.

TABLE VII

ATTITUDE TOWARD GROUP HOMES
SCORES IN RANK ORDER

\begin{tabular}{cc}
\hline $\begin{array}{c}\text { Neighborhood A } \\
\mathrm{n}=28\end{array}$ & $\begin{array}{c}\text { Nelghborhood } \mathrm{B} \\
\mathrm{n}=26\end{array}$ \\
\hline & \\
2.6 & 2.8 \\
2.6 & 2.8 \\
2.8 & 3.2 \\
2.8 & 3.2 \\
3.2 & 3.2 \\
3.2 & 3.4 \\
3.2 & 3.4 \\
3.4 & 3.6 \\
3.4 & 3.6 \\
3.6 & 3.6 \\
3.6 & 3.8 \\
3.6 & 3.8 \\
3.8 & 3.8 \\
4.0 & 3.8 \\
4.0 & 4.0 \\
4.0 & 4.0 \\
4.0 & 4.0 \\
4.2 & 4.0 \\
4.2 & 4.2 \\
4.2 & 4.2 \\
4.4 & 4.2 \\
4.4 & 4.6 \\
4.6 & 4.6 \\
4.6 & 4.6 \\
4.8 & 4.8 \\
4.8 & 5.0 \\
5.0 & \\
5.0 & 3.85 \\
\hline 3.86 & \\
\hline
\end{tabular}

Again a $t$ test of statistical significance was not done as the results are so similar as to be virtually identical.

Table VIII ( $p .27$ ) shows the average response of both neighborhoods to each of the first five statements in part two of the questionnaire. 
TABLE VIII

AVERAGE RESPONSES TO STATEMENTS REGARDING ATT ITUDES TOWARD GROUP HOMES

\begin{tabular}{lc}
\hline & Neighborhood \\
statements & A $B$ \\
\hline
\end{tabular}

1. If group homes for mentally retarded people were in my neighborhood I would fear for the safety of neighborhood children..........4 4.07 4.15

2. I belleve the property value of my home would drop if group homes were in my neighborhood.... 3.36 3.19

3. If group homes are placed in the community, I would want them in other neighborhoods, not in my neighborhood........................... 3.78

4. I believe mentally retarded people are better cared for in institutions where they are safe from harm................................ $3.89 \quad 3.77$

5. I believe mentally retarded people are more likely to steal.............................. $\frac{4.18}{3.86} \frac{4.30}{3.85}$

The highest numerical response, in both neighborhoods, was to statement five, the second highest to statement one, which appears to indicate a general disagreement with the statements that the mentally retarded would be a threat to children or would steal. This result seems to colncide with the attitude indicated in part one of the questionnaire that the mentally retarded are not perceived as dangerous.

The lowest numerical response, again in both neighborhoods, was to statement two. Thus 1 t appears that the most common objection to the entry of group homes into these neighborhoods would be that property values may drop.

Question six of part two of the questionnaire asks the respondents 
how they would vote on a zoning change to allow group homes into their neighborhood. Would they vote yes to permit them, or no not to permit them. Table IX shows the number of yes and no responses in each neighborhood.

TABLE IX

RESPONSES TO HYPOTHETICAL ZONING CHANGE

TO PERMIT GROUP HOMES IN NEIGHBORHOOD*

\begin{tabular}{|c|c|c|}
\hline $\begin{array}{l}\text { How respondents would vote on } \\
\text { hypothetical zoning change }\end{array}$ & $\begin{array}{c}\text { Neighborhood } \\
\text { A }\end{array}$ & $\begin{array}{c}\text { Neighborhood } \\
\text { B } \\
\end{array}$ \\
\hline $\begin{array}{l}\text { Yes..... } \\
\text { No...... }\end{array}$ & $\begin{array}{cc}\mathrm{n} & \% \\
21 & 84 \\
\frac{4}{25} & \frac{16}{100 \%}\end{array}$ & $\begin{array}{cc}n & \% \\
20 & 83.3 \\
\frac{4}{24} & \frac{16.7}{100.0 \%}\end{array}$ \\
\hline
\end{tabular}

The results shown in Table IX are virtually identical and a chi square test shows no significant difference between the two neighborhoods in how they would vote on such a zoning change. The majority of respondents in both neighborhoods appear willing to permit group homes in their neighborhood.

In analyzing the data to determine commonalities among the eight respondents who said they would vote no to a zoning change, it was discovered that they had all strongly agreed or agreed that the presence of group homes in their neighborhood would lower their property values. Table X (p. 29) compares the responses of all respondents from both neighborhoods on the zoning change question, with the responses to statement two, part two of the questionnaire ("I believe the property value of my home would drop if group homes were in my neighborhood.") 
TABLE X

RELATION OF FEAR OF LOSS OF PROPERTY VALUE TO VOTING FOR ZONING CHANGE TO PERMIT GROUP HOMES*

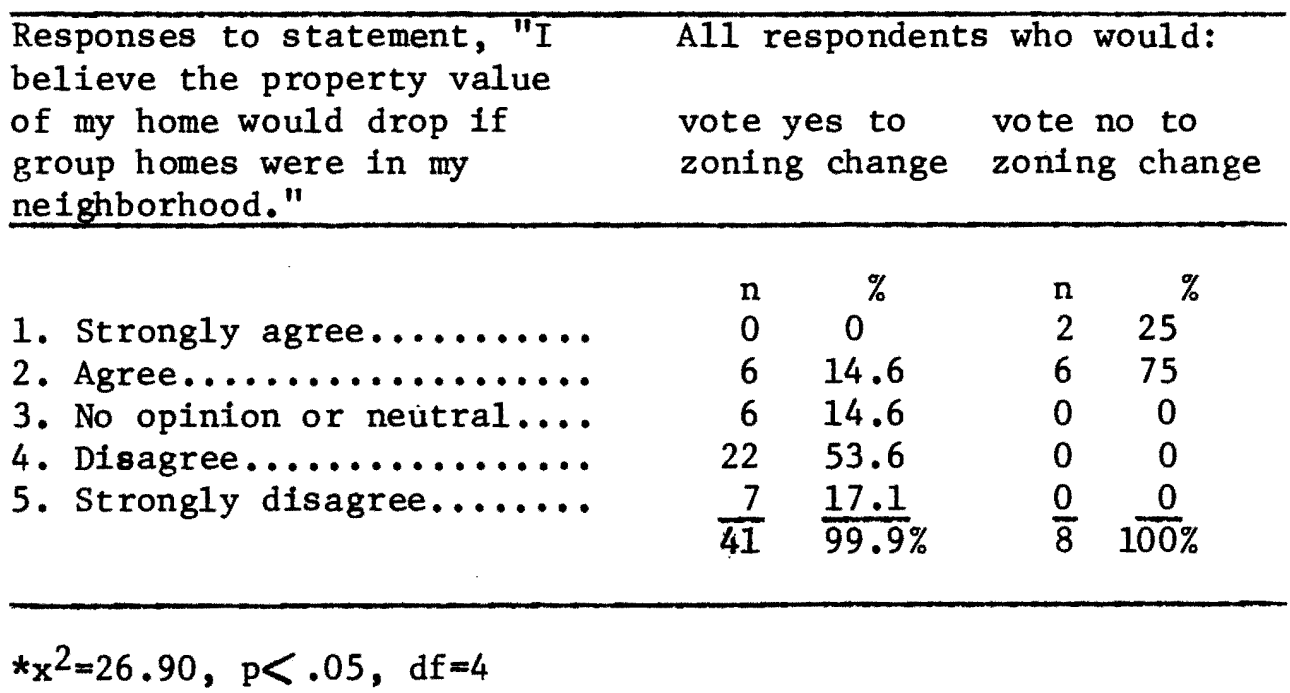

A chi square test showed a significant relationship between a belief that the entry of group homes would lower property values and voting against a zoning change to allow entry of group homes. Of those who would vote yes to a zoning change, a majority $(70.7 \%)$ either disagreed or strongly disagreed with statement two, while all of those who would voteno agreed or strongly agreed.

A further analysis of the data revealed a relationship between resident status and voting to permit entry of group homes into one's neighborhood. Table XI ( $p .30)$ compares these two variables.

About one half of those who would vote to permit a group home in their neighborhood are renting their residence. It is interesting to note however, that disregarding the votes of the renters, a zoning change to permit group homes is still supported by a majority, though a less commanding one. 
TABLE XI

RELATION OF RESIDENT STATUS TO VOTING FOR ZONING CHANGE TO PERMIT GROUP HOMES*

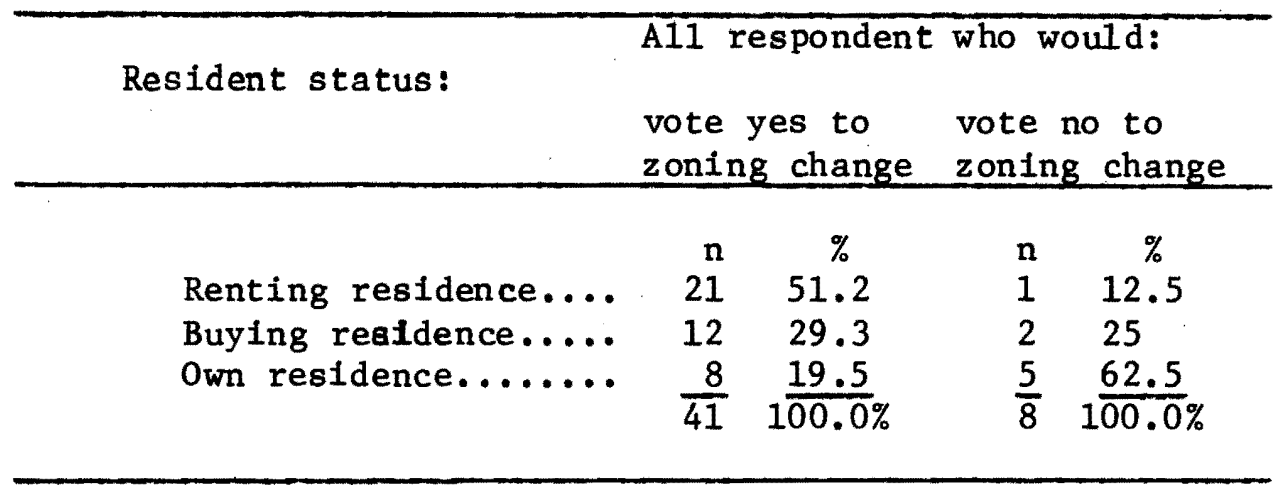

$*_{x}^{2}=6.95, p<.05, d f=2$

A chi square test showed a significant relationship between resident status and voting for a zoning change to permit entry of group homes. Renters are more likely to vote yes than those who are buying their home, and those who are buying their home are more likely to vote yes than those who own their home. 


\section{CHAPTER VI}

CONCLUDING DISCUSSION

\section{CONCLUSIONS}

These two neighborhoods are very simflar in terms of the demographic data collected in this research. The major difference is the presence and neighborhood awareness of three group homes for the mental1y retarded in Neighborhood $A$ and the absence of group homes in Neighborhood B (with the exception of a home for M.E.D. clients of which only four respondents were aware).

The attitudes toward the mentally retarded and toward the entry and presence of group homes, as measured by the questionniare in this survey, were virtually identical in both neighborhoods. A tentative conclusion can be drawn that, given the type of neighborhood surveyed in this research, the presence of group homes has no effect on attitudes toward the mentally retarded or toward group homes. Such presence neither makes attitudes significantly more positive nor more negative, and neither does it increase the number of people tolerant of or opposed to group homes.

While this conclusion can be drawn from and supported by the results of this research, it was this researcher's subjective impression while conducting the survey that there is a difference in the two neighborhoods. While the presence of group homes in Neighborhood A has not significantly altered attitudes or alliances, it may have crystalized them. That is, those respondents in Neighborhood A who were opposed to 
group homes appeared more adamant in their opposition, while those who were more tolerant had words of praise for the group homes in their neighborhood.

Another tentative conclusion that can be drawn from this research is that, at least in the type of neighborhood surveyed, the mentally retarded are not perceived as dangerous, a threat to children, or like1y to steal. As mentioned earlier in this paper, part of the rationale for the institutionalization of the mentally retarded in the first half of this century was the perception of them as a "menace" to society. If indeed this perception was widely held, it appears to be on the wane today.

A final conclusion is that a majority of residents in the type of neighborhood surveyed would not be opposed to a group home in their neighborhood. The minority who would oppose group homes is more likely to be buying or own a residence and is concerned with a possible loss of property value.

\section{LIMITATIONS}

The conclusions that can be drawn from this research have limitations. This survey was conducted in two older, middle class neighborhoods with a mixture of commercial, multiple dwelling residential, and single dwelling residential zoning in proximity to the downtown area of an Oregon city with a population of approximately 80,000 . The results of this survey could be generalized to other simflar neighborhoods, but the results could not be sald to represent a general "community" attitude.

Also, there are limitation of reliability and validity. The 
questionnaire has been used only in this one exploratory research and its reliability can not be said to have been tested. The main concern of validity is the propensity of people to say one thing and do another. It can only be assumed guardedly that the responses to this questionnaire reflect actual attitudes and that the respondents, if faced with an actual zoning election, would vote as they indicated in this questionnaire.

\section{IMPL ICAT IONS}

Despite these limitations, this research can provide useful information to those concerned with the establishment of nelghborhood group homes.

First, it appears that there is a good deal of support and acceptance for group homes in the type of neighborhood surveyed. There is also opposition. Though that opposition may be in a minority it can, as it has in certain pest instances, successfully resist the entry of group homes. The majority who would support a group home may be less inclined than the opposition to become involved in zoning disputes. Thus, those who would establish a group home may need to identify and determine the strength of their support before trying to enter a specific nel ghborhood.

Second, the primary stated complaint of those in opposition to group homes is a fear of a loss of property value. Those seeking to establish a group home may need to be prepared to address this fear. Third, many general complaints are made about group homes. The statements that neighborhood residents would fear their mentally retarded neighbors or that neighborhoods which now have group homes are dis- 
satisfied with them are false claims made by those who have listened only to a disgruntled minority.

\section{RECOMMENDATION FOR FUTURE RESEARCH}

Research to determine what effect the entry of group homes has on property values could provide useful information to those concerned with deinstitutionalization. It is this researcher's assumption that the effect, if any, is minimal. If that is proven to be the case, such factual information may help alleviate the fears and fantasies of certain community residents.

This research was done in one type of neighborhood. Further studles in other types of nelghborhoods and among various populations could more precisely define the nature of community attitudes toward the mentally retarded. 


\section{REFERENCES}

1. Bergman, Joel S., ed. Community Homes for the Retarded. Lexington, Massachusetts: D.C. Heath \& Company, 1975.

2. Best, Harry. Public Provision for the Mentally Retarded in the United States. Worcester, Massachusetts: Heffernan Press Inc., 1965.

3. Daily, Wayne F., et al. "Attendant Behavior and Attitudes Toward Institutionalized Retarded Children." American Journal of Mental Deficiency, Vo1. 78, No. 5 (1974), 586-591.

4. E11is, Norman R., ed. International Review of Research in Mental Retardation, Vo1. 7. New York: Academic Press, 1974.

5. Goroff, Norman N. "Research and Community P1acement - An Exploratory Approach." Mental Retardation, Vo1. 5, No. 4 (Aug, 1964), 17-19.

6. Greenbaum, Joseph J. and Dorly D. Wang. "A Semantic-Differential Study of the Concepts of Mental Retardation." Journal of General Psychology, Vo1. 73 (1965), 257-272.

7. Kanner, Leo. A History of the Care and Study of the Menta11y Retarded. Springfield, Illino 1s: Charles C. Thomas, 1964.

8. Kresse1, Laurence. "The Community Residence Movement: Land Use Conflicts and Planning Imperatives." New York University Review of Law and Soclal Change, Vo1. V, No. 2 (Spring, 1975), 137-162.

9. Lippman, Leopold D. Attitudes Toward the Handicapped. Springfield, Illino 1s: Charles C. Thomas, 1972.

10. Oregon Comprehensive Mental Retardation Planning Project. First Steps Toward Comprehensive Mental Retardation Services in Oregon. Salem, Oregon: State publication, 1965.

11. Peterson, Gerald F. "Factors Related to the Att1tudes of Nonretarded Children toward their EMR Peers." American Journal of Mental Deficiency, Vol. 79, No. 4, (1974), 412-416.

12. President's Panel on Mental Retardation. A Proposed Program for National Action to Combat Mental Retardation. Washington, D.C.: U.S. Government Printing Office, October, 1962.

13. Talkington, Larry $W$. Institut 1ons, Their Role and Future. Developmental Disabilities Research Series No. 9, Falrview Hospital and Training Center, Salem, Oregon, April, 1971.

14. Taylor, Hayward G. "Social Perceptions of the Mentally Retarded." Journal of Clintcal Psychology, Vol. 31, No. 1 (1975), 100-102. 
15. Wolfensberger, Wolf. "The Origin and Nature of Our Institutional Models." Changing Patterns in Residential Services for the Mentally Retarded. Eds., Robert B. Kugel and Wolf Wolf ensberger. Washington, D.C.: A President's Committee on Mental Retardation Monograph, 1969.

16. Wolfensberger, Wolf. The Principle of Normalization in Human

Services. Toronto: Leonard Crainford, 1972. 
APPENDIX

QUESTIONNA IRE

Part One: General attitudes toward the mentally retarded.

The following rating scales consist of contrasting adjectives. Please circle the number, on a 1 to $7 \mathrm{scale,}$ that indicates how you feel toward mentally retarded people.

For example, if you were being asked to rate douglas fir trees as to whether they were ugly or beautiful, your responses might look something 1ike this:

DOUGLAS FIR TREES

$\begin{array}{lllllllll}\text { beautiful } & 1 & 2 & \text { (3) } & 4 & 5 & 6 & 7 & \text { ugly }\end{array}$

This response indicates a feeling that douglas fir trees are more beautiful than ugly, but not the most beautiful object you have seen.

FEELINGS TOWARD MENTALLY RETARDED PEOPLE

\begin{tabular}{|c|c|c|c|c|c|c|c|c|}
\hline valuable & 1 & 2 & 3 & 4 & 5 & 6 & 7 & useless \\
\hline clean & 1 & 2 & 3 & 4 & 5 & 6 & 7 & dirty \\
\hline $\begin{array}{l}\text { easy to get } \\
\text { along with }\end{array}$ & 1 & 2 & 3 & 4 & 5 & 6 & 7 & $\begin{array}{l}\text { hard to get } \\
\text { along with }\end{array}$ \\
\hline neat & 1 & 2 & 3 & 4 & 5 & 6 & 7 & sloppy \\
\hline not dangerous & 1 & 2 & 3 & 4 & 5 & 6 & 7 & dangerous \\
\hline reliable & 1 & 2 & 3 & 4 & 5 & 6 & 7 & unreliable \\
\hline healthy & 1 & 2 & 3 & 4 & 5 & 6 & 7 & sick \\
\hline calm & 1 & 2 & 3 & 4 & 5 & 6 & 7 & emotional \\
\hline
\end{tabular}


QUESTIONNAIRE

Part Two: Attitudes toward the presence and entry of group homes.

The following verbal instructions were given to each respondent:

"The next seven question I will ask you are about your attitudes regarding group homes for the mentally retarded. Let me first explain what a group home is.

"A group home for the retarded is a private home maintained and operated for the care, boarding, housing, and training of six or more mentally retarded persons. Residents in group homes are usually not related to each other or to the staff of the home. Group homes employ supervisory and training staff, and at least one staff person is on duty whenever one or more residents are in the home. Residents in group homes usually go out during the day to work or training situations in the community. Do you have any questions?"

Respondents were asked to give one of the following responses:

Strongly agree Agree No opinion Disagree Strongly disagree $\begin{array}{lllll}1 & 2 & 3 & 4 & 5\end{array}$

1. If group homes for mentally retarded people were in my neighborhood I would fear for the safety of neighborhood children.

2. I belleve the property value of my home would drop if group homes were in my neighborhood.

3. If group homes are placed in the community, I would want them in other neighborhoods, not in my neighborhood.

4. I belleve mentally retarded people are better cared for in institutions where they are safe from harm.

5. I believe mentally retarded people are more likely to steal.

The last two questions are yea or no questions:

6. If you had to vote today on a zoning change for your neighborhood to perint group homes for the mentally retarded, would you vote:

Yes, permit them in my neighborhood

No, do not permit them In my neighborhood

7. Are there now any group homes for mentally retarded people with in 10 blocks of your home?

Yes

No

I do not know 


\section{QUESTIONNAIRE}

Part Three: Demographic data.

1. Occupation of respondent.

2. Age of respondent.

3. Sex of respondent.

4. Number of people residing in respondent's home.

5. Resident status of respondent: a. renting

b. buying

c. own

6. Number of years respondent has lived in neighborhood.

7. Last years income of respondent's household:
a.
0 to $\$ 10,000$
b. $\$ 10,000$ to $\$ 20,000$
c. $\$ 20,000$ and above 